\title{
B-Vitamins Determination in Donkey Milk
}

\author{
Silvia Vincenzetti ${ }^{1, *} \mathbb{C}^{\circ}$, Stefania Pucciarelli ${ }^{1}{ }^{\circ}$, Giuseppe Santini ${ }^{1}$, Yulia Klimanova ${ }^{1}$, \\ Valeria Polzonetti ${ }^{1}$ (D) and Paolo Polidori ${ }^{2}$ (D) \\ 1 School of Biosciences and Veterinary Medicine, Via Gentile III da Varano, 62032 Camerino (MC), Italy; \\ stefania.pucciarelli@unicam.it (S.P.); giuseppe.santini@unicam.it (G.S.); yulia.klimanova@unicam.it (Y.K.); \\ valeria.polzonetti@unicam.it (V.P.) \\ 2 School of Pharmacy, University of Camerino, 62032 Camerino (MC), Italy; paolo.polidori@unicam.it \\ * Correspondence: silvia.vincenzetti@unicam.it; Tel.: +39-0737402722
}

Received: 30 May 2020; Accepted: 21 July 2020; Published: 23 July 2020

\begin{abstract}
Background: Donkey milk is used in infant nutrition for the treatment of children affected by cow's milk protein allergy, thanks to its hypo-allergenicity, mainly due to its protein profile, which is very close to that of human milk. Furthermore, donkey milk is characterized by the presence of a fair amount of bioactive proteins, that may have a positive impact on human health. Despite the presence of numerous articles that describe the chemical composition and nutraceutical properties of donkey milk, few works have been performed to determine its vitamin profile; therefore, the purpose of this work is to give further information on the B-vitamins profile of donkey milk. Methods: B-vitamins have been determined through a reversed-phase liquid chromatography analysis. Results: The results indicated that donkey milk $(\mathrm{DM})$ contains thiamine $0.661 \pm 0.26 \mu \mathrm{M}$, riboflavin $0.168 \pm 0.04 \mu \mathrm{M}$, nicotinic acid $18.75 \pm 1.92 \mu \mathrm{M}$, pyridoxine $5.38 \pm 3.35 \mu \mathrm{M}$, and folic acid $0.83 \pm 0.08 \mu \mathrm{M}$. Conclusions: Donkey milk contains a high quantity of nicotinic acid, known for its lipid-lowering effect, and a good amount of vitamin B6 and folic acid, the latter very important for children's growth. To notice, vitamin $\mathrm{B} 6$ has been determined for the first time in donkey milk.
\end{abstract}

Keywords: donkey milk; B-vitamins; RP-HPLC

\section{Introduction}

Vitamins are essential compounds for human health, necessary in small quantities that must be introduced with the diet. These important compounds are involved in several functions; some of them are part of the molecular structure of many coenzymes necessary in different enzymatic reactions that occur in metabolic processes [1]. In bovine milk, vitamins $\mathrm{A}, \mathrm{K}$, and $\mathrm{E}$, are the most abundant among the fat-soluble ones. Vitamin A is found in bovine milk $(0.35-3.14 \mu \mathrm{M})$ and derivatives, mainly as retinyl ester, and its content is influenced by various factors, such as feeding, lactation period, climatic conditions, and livestock breed [2,3].

In bovine milk, vitamin $\mathrm{E}$ is present as $\alpha$-tocopherol (mean content: $0.46-4.64 \mu \mathrm{M}$ ), and its presence is influenced by livestock breed. It was reported in the literature that feeding the bovine with rapeseed led to an increased amount in the milk of monoenoic fatty acids and vitamin E [2,4]. The vitamin $\mathrm{K}$ content in the bovine milk is very low; it ranges from 0.007 to $0.015 \mu \mathrm{M}$, and depends on the amount of fat, but its content shows a seasonal variation linked to the feeding and lactation period [2].

Among water-soluble vitamins, and in particular B-vitamins, Rutten and co-workers [5] found that vitamin B12 content in Dutch Holstein Friesian cow's milk varied from $0.73 \times 10^{-3} \mu \mathrm{M}$ to $93 \times 10^{-3} \mu \mathrm{M}$, with a mean concentration of $3.23 \times 10^{-3} \mu \mathrm{M}$. These authors established a correlation between animals' genetic variation and vitamin B12 content; they suggested that the genotype of the cow influences the microbial population in the rumen which, in turn, affects the vitamin B12 content that is synthesized by 
these microorganisms [5]. In other works [6,7], it was found that the vitamin content of vitamin B12 in bovine milk is higher in colostrum than in mature milk, and that this value depends on the animal diet. These authors found a vitamin B12 content of $2.8 \times 10^{-3} \mu \mathrm{M}$ at day 11 of lactation, and $2.4 \times 10^{-3} \mu \mathrm{M}$, at day 39 of lactation.

The folate (vitamin B9) content in bovine milk can show wide variations due to factors such as cattle nutrition, the presence of antioxidant vitamins, and the presence of oxygen [2]. In bovine milk, folate concentration has the highest concentration in the colostrum $(0.99 \mu \mathrm{M})$, and then decreases during the lactation period: at day 11 of lactation, the concentration is $0.21 \mu \mathrm{M}$, whereas at 39 days of lactation, it is $0.18 \mu \mathrm{M}[6]$.

Riboflavin (vitamin B2) content in bovine milk ranges from 2.12 to $6.91 \mu \mathrm{M}$; in pasteurized whole bovine milk, the amount of this vitamin is around $4.8 \mu \mathrm{M}[2,8]$. Furthermore, Poulsen and co-workers found that organic dairy cows milk shows a seasonal variation on riboflavin content that reaches the highest value during the wintertime [8]. Thiamine (vitamin B1), niacin (vitamin B3), and vitamin B6 content in bovine milk ranged from $0.59-2.37 \mu \mathrm{M}, 2.43-16.24 \mu \mathrm{M}$, and 1.0-11.23 $\mu \mathrm{M}$, respectively [2,3,9]. Therefore, it is interesting to note that one cup of bovine milk supplies up to $62 \%$ of vitamin B12, $47 \%$ of riboflavin, and $23 \%$ of pantothenic acid RDI [3].

Donkey milk (DM) is used in infant nutrition in treating children affected by cow's milk protein allergy (CMPA), thanks to its hypo-allergenic properties, mainly due to the low total casein content and the protein profile, which is very close to that of human milk [10-12]. Besides, DM is characterized by the presence of a fair amount of some bioactive proteins, such as lysozyme, lactoferrin and lactoperoxidase, that have a positive impact on human health [13-16]. DM lactose content is similar to that of human milk. Lactose is involved in bone mineralization, since it stimulates the intestinal absorption of calcium in the infant. The fat content is much lower than that observed in human and bovine milk [17]. The Ca/P ratio in donkey milk is lower compared to bovine milk, but higher if compared to human milk [18]. Although in the literature several articles describe the chemical composition and nutraceutical properties of donkey milk, few works have been performed to determine the vitamin profile of this milk. In a previous work, it was found that the vitamin C content in DM is $0.32 \mathrm{mM}$ [19], very close to the value detected in human milk and in donkey milk from Indian small grey breed $(0.28 \mathrm{mM})[20,21]$, but higher than the one determined in bovine milk $(28.4-170.3 \mu \mathrm{M})$ [22]. Vitamin C is an antioxidant agent that acts as a free radical scavenger. In another work, the vitamin $\mathrm{D}$ content in DM was determined, the concentration resulted to be $0.042 \mu \mathrm{M}$ for the vitamin $\mathrm{D}_{2}$, and $0.016 \mu \mathrm{M}$ for the vitamin $\mathrm{D}_{3}$. These values were higher if compared to those found in human milk and bovine milk $(0.008 \mu \mathrm{M})$ [23]. The same authors showed that the vitamin $\mathrm{D}$ content has a seasonal variation, since it is more concentrated in summer compared to winter, probably because of the greater sun exposure of the animals. Furthermore, it was found that this vitamin is not thermostable, and this fact led to a significant reduction of this vitamin in the thermally treated DM [23]. In a very recent study, the physicochemical composition, minerals, vitamins, amino acids, and the fatty acid profile of donkey milk from Indian small grey breed have been determined [21]. These authors found that vitamins A, B12 and B2 were below the limit of quantification, and determined the content of vitamin B1 $(2.9 \mu \mathrm{M})$, niacin $(100 \mu \mathrm{M})$, vitamin $\mathrm{E}(3.4 \mu \mathrm{M})$, and vitamin $\mathrm{C}(0.28 \mathrm{mM})$.

With the present work, we would give further information on the vitamin content in donkey milk from the Amiata breed, especially as regards the B-vitamins. At this purpose, a reversed-phase liquid chromatography (RP-HPLC) method has been used for the determination of thiamine (vitamin B1), riboflavin (vitamin B2), nicotinic acid (niacin, vitamin B3), nicotinamide (niacinamide), pyridoxine hydrochloride (vitamin B6), folic acid (vitamin B9) and cyanocobalamin (vitamin B12). 


\section{Materials and Methods}

\subsection{Chemicals}

All reagents and solvents were HPLC or LC-MS grade. Vitamin standard (thiamine hydrochloride, vitamin B1; riboflavin, vitamin B2; nicotinic acid, niacin; nicotinamide; pyridoxine hydrochloride, vitamin B6; folic acid, vitamin B9; cyanocobalamin, vitamin B12), trichloroacetic acid (TCA), glacial acetic acid, methanol and octane sulphonic acid were purchased from Sigma-Aldrich (St. Louis, MO, USA). Ultra-pure water was prepared using a Milli-Q water system equipped with a $0.22 \mu \mathrm{m}$ point-of-use membrane filter cartridge (Millipore-Waters, Milford, MA, USA).

\subsection{Donkey Milk Samples Preparation}

The experimental protocol was conducted in compliance with the requirements of the Animal Ethics Committee of the University of Camerino. Bulk raw DM samples (around $50 \mathrm{~mL}$ ) were collected during routine herd management (machine milking once per day) from 10 asses, belonging to Amiata breed at midstage of lactation (around 120-140 days after parturition), reared in a local farm (Mamma Asina, Colmurano, MC, Italy) that produces DM for human consumption according to the EU Regulation 853/2004. After milking, DM was transported in a refrigerated bag $\left(+4{ }^{\circ} \mathrm{C}\right)$ to the laboratories, to be processed and analyzed. The samples were protected from light by wrapping tubes and flasks with aluminum foil. Before being analyzed for the vitamin content, the milk samples were processed according to the method described by Albalá-Hurtado and co-workers [24]. The vitamin extraction procedure from DM samples was performed in a darkened room. Briefly, to $10.5 \mathrm{~g}$ of sample, $1 \mathrm{~g}$ of TCA was added, and the mixture was stirred for $10 \mathrm{~min}$ over a magnetic stirring plate. Subsequently, the mixture was centrifuged for $10 \mathrm{~min}$ at $1250 \mathrm{~g}$, and the first supernatant was recovered. To the precipitate, $3 \mathrm{~mL}$ of $4 \%$ TCA was added, mixed for $10 \mathrm{~min}$, and then centrifuged again (same conditions as above). After centrifugation, the supernatant was recovered and combined with the first supernatant. These two acid extracts were brought to $10 \mathrm{~mL}$ with $4 \%$ TCA, and filtered through a $0.45 \mu \mathrm{m}$ filter (Whatman, Maidstone, UK), before being subjected to the RP-HPLC analysis. Three determinations were performed by adding a known amount of thiamine $(31 \mu \mathrm{M})$ to the DM sample before the TCA treatment, for the recovery calculation.

\subsection{Reversed Phase-High Performance Liquid Chromatography (RP-HPLC) Analysis}

The chromatographic courses were performed according to Albalá-Hurtado and co-workers [24], using an HPLC Agilent 1260 Infinity LC System (Agilent Technologies), consisting of a 1260 Infinity Quaternary Pump, 1260 Infinity Multisampler, 1260 Infinity Multicolumn Thermostat, and 1260 Infinity Diode Array Detector. Data were acquired by the OpenLab Software (Agilent technologies). The column was a C18 HiQSil HS, 5 mm, 4.6 mm i.d, 250 mm (Kya Tech Corporation, Tokyo, Japan). The mobile phase was: methanol (85:15), containing 0.5\% triethylamine, 2.4\% glacial acetic acid, and $5 \mathrm{mM}$ octane sulfonic acid ( $\mathrm{pH}$ 3.6). The analyses were carried out isocratically at $25^{\circ} \mathrm{C}$, with a flow rate of $0.9 \mathrm{~mL} / \mathrm{min}$; the total run was $40 \mathrm{~min}$. The injection volume was $100 \mu \mathrm{L}$. The eluent was detected at 254 and $270 \mathrm{~nm}$. The analyses were performed in quintuplicate.

Standard solutions of vitamin B1 $(0.1 ; 0.3 ; 0.5 ; 0.75 ; 1.5 ; 2.0 ; 3.1 ; 6.2 ; 9.3 ; 15.5 ; 18.7 \mu \mathrm{M})$, vitamin B2 $(0.5 ; 0.75 ; 1.0 ; 1.5 ; 2.0 ; 5.0 ; 7.5 ; 10 ; 15 \mu \mathrm{M})$, nicotinamide $(0.3 ; 0.5 ; 0.75 ; 1.0 ; 1.5 ; 2.0 ; 3.0 ; 5.0 ; 7.5 \mu \mathrm{M})$, nicotinic acid $(0.75 ; 1.0 ; 2.0 ; 3.0 ; 5.0 ; 7.5 ; 10.0 ; 15.0 ; 20.0 \mu \mathrm{M})$, vitamin B6 (0.75; $1.0 ; 2.0 ; 3.0 ; 5.0 ; 7.5 ; 10.0$; $15.0 ; 20.0 \mu \mathrm{M})$ and folic acid $(0.3 ; 0.5 ; 0.75 ; 1.0 ; 1.5 ; 2.0 ; 3.0 ; 5.0 ; 7.5 \mu \mathrm{M})$ were prepared in ultra-pure water. A $100 \mu \mathrm{L}$ solution of each standard was separately loaded on the RP-HPLC column. The area of each standard peak was measured using the valley-to-valley integration mode, and quantification was achieved by a calibration curve obtained relating the concentration $(\mu \mathrm{M})$ of each standard loaded in the column to the respective peak area. The quantity of vitamin B1, B2, nicotinamide, nicotinic acid, vitamin B6, folic acid in donkey milk was determined using the calibration curve. The recovery (\%) 
was calculated by the following equation: Recovery $(\%)=\frac{C t-C s}{C a} \times 100(C t$ : concentration obtained from the fortified sample; Cs: concentration obtained from the blank; $C a$ : sample concentration added).

\section{Results and Discussion}

\section{B-Vitamins Determination in Donkey Milk by RP-HPLC}

Vitamins are essential for life, and their deficiency induces specific diseases. B-vitamins deficiency can be caused by (a) low-quality diet in terms of micronutrient supply; (b) intestinal disorders that can lead to B-vitamin malabsorption; (c) Crohn's disease (vitamin B3); (d) pernicious anemia (vitamin B12); (e) chronic alcoholism (vitamins B1, B2, B3); (f) age; worm infections (vitamins B1 and B6) [25].

In this work, some B-vitamins have been determined in the milk of the donkey from the Amiata breed. Table 1 shows retention times, and the equation of the calibration lines for each vitamin standard, with the respective correlation coefficient $\left(\mathrm{R}^{2}\right)$ values, obtained after the RP-HPLC analysis. It should be noted that the $\mathrm{R}^{2}$ is equal to 0.99 for all vitamin standards, indicating the very good linearity of the method. The obtained recovery for thiamine was $95 \%$.

Table 1. Retention time (RT) and equation of the calibration lines for each vitamin standard together with the respective $R^{2}$ values.

\begin{tabular}{cccc}
\hline Vitamin Standard & RT (min) & Equation & $\mathbf{R}^{\mathbf{2}}$ \\
\hline Thiamine (vitamin B1) & $24.2-24.6$ & $\mathrm{y}=33.53 \mathrm{x}-3.8732$ & 0.992 \\
\hline Riboflavin (vitamin B2) & $19.4-19.9$ & $\mathrm{y}=121.82 \mathrm{x}-0.9437$ & 0.999 \\
\hline Nicotinic acid & 4.27 & $\mathrm{y}=15.323-0.3843$ & 0.999 \\
\hline Nicotinamide & $5.8-6.0$ & $\mathrm{y}=10.343 \mathrm{x}+3.4316$ & 0.995 \\
\hline Pyridoxine (vitamin B6) & 8.14 & $\mathrm{y}=11.605 \mathrm{x}-3.3578$ & 0.999 \\
\hline Folic acid & $12.2-13.4$ & $\mathrm{y}=110.71 \mathrm{x}-15.488$ & 0.999 \\
\hline Cyanocobalamin (vitamin B12) & 27.5 & $\mathrm{y}=48.13 \mathrm{x}+0.6341$ & 0.997 \\
\hline
\end{tabular}

Figure 1 shows a typical chromatogram obtained for donkey milk after the RP-HPLC analysis. The concentrations of vitamins B1 and B2, nicotinamide, nicotinic acid, vitamin B6 and folic acid, determined by the RP-HPLC method, are shown in Table 2 and values are compared with those found in the literature for human $[20,26]$, bovine, $[2,3,27]$, mare [28,29] and goat milk [30,31].

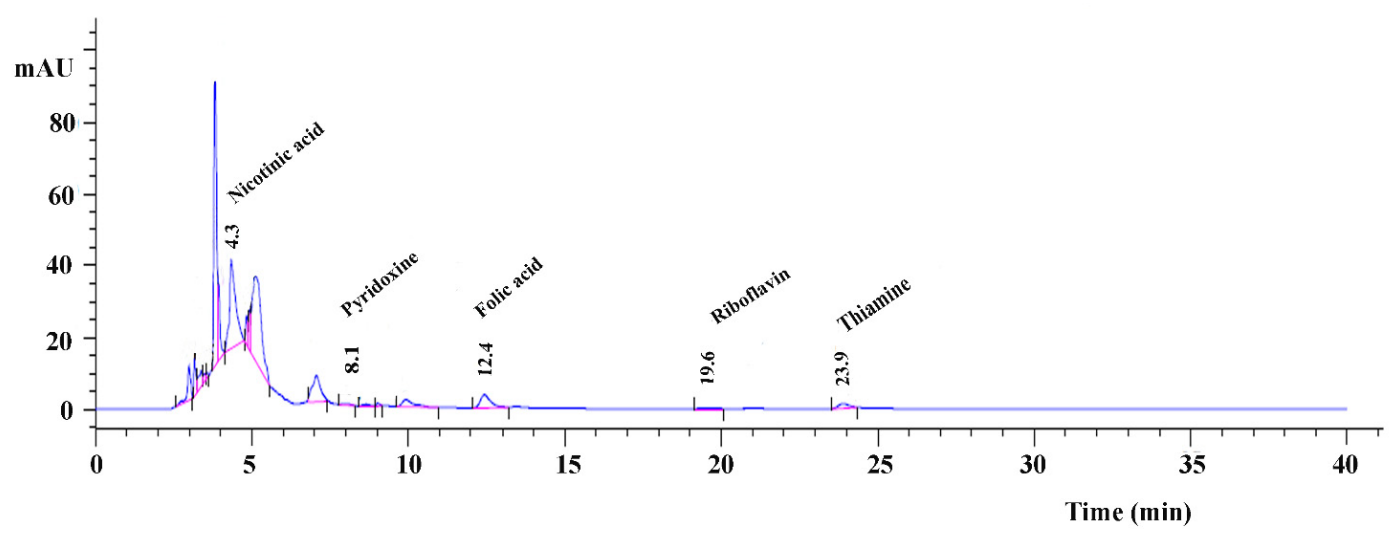

Figure 1. Chromatographic profile of B-vitamins from donkey milk obtained after RP-HPLC analysis (Column: C18 HiQSil HS, 5 m, $4.6 \mathrm{~mm}$ i.d, $250 \mathrm{~mm}$, connected to an Agilent 1260 Infinity LC System, Agilent Technologies). 
Table 2. Content of B-vitamins in donkey milk (DM) and comparison with human milk (HM), bovine milk (BM), mare milk (MM) and goat milk (GM).

\begin{tabular}{cccccc}
\hline Vitamin & DM $(\mu \mathbf{M})$ & HM $(\mu \mathbf{M}) *$ & $\mathbf{B M}(\mu \mathbf{M}) \S$ & $\mathbf{M M}(\mu \mathbf{M}){ }^{\circ}$ & $\mathbf{G M}^{*}(\mu \mathbf{M}) * *$ \\
\hline Thiamine (vitamin B1) & $0.661 \pm 0.26$ & 0.12 & $0.59-2.37$ & $0.68-1.38$ & 1.6 \\
Riboflavin (vitamin B2) & $0.168 \pm 0.04$ & 0.079 & $2.12-6.91$ & $0.076-1.28$ & 4.5 \\
Nicotinic acid (niacin) & $18.75 \pm 1.92$ & 4.64 & $2.43-16.24$ & $0.57-1.14$ & 22.5 \\
Nicotinamide & n.d. & - & - & - & - \\
Pyridoxine (vitamin B6) & $5.38 \pm 3.35$ & 0.480 & $1.00-11.23$ & $0.49-3.6$ & 2.7 \\
Folic acid (vitamin B9) & $0.83 \pm 0.082$ & 0.365 & $0.022-0.226$ & $0.29 \times 10^{-3}$ & 0.020 \\
Cyanocobalamin & n.d. & - & $3.3 \times 10^{-3}$ & $0.22 \times 10^{-3}$ & $0.51 \times 10^{-3}$ \\
\hline
\end{tabular}

Thiamine concentration in DM from the Amiata breed is $0.661 \mu \mathrm{M}$, a value close to that reported for the bovine milk [2,3] and mare's milk [28]; about 6-fold higher to that the value observed in the human milk [20] but lower to the value $(2.9 \mu \mathrm{M})$ found by Nayak and co-worker [21] in DM from Indian small grey breed, and lower than the value found in goat milk $(1.6 \mu \mathrm{M})[30,31]$. The difference in vitamin content between one breed and another may be due to genetic factors (animal breed), but also it can be possible to find differences within the same breed, and this may be caused by several factors, such as feeding, lactation period, season, climatic conditions [3]. Thiamine is the precursor of the thiamine pyrophosphate (TPP), a cofactor required for the proper functioning of four enzymes involved in the metabolism: pyruvate dehydrogenase complex (convert pyruvate in acetyl-CoA), $\alpha$-ketoglutarate dehydrogenase complex (an enzyme of the tricarboxylic acid cycle), transketolase (an enzyme of the pentose phosphate shunt), and branched-chain $\alpha$-ketoacid dehydrogenase complex (an enzyme of the branched-chain amino acids metabolism). In light of this, a thiamine deficiency can cause alteration in brain functions, neurotransmitters, inflammation, and oxidative stress. Besides, thiamine deficiency can cause cardiovascular system impairment, due to the pyruvate accumulation that leads to increased lactic acid production and consequently increased ventricular filling pressures and oxygen consumption [32]. Furthermore, thiamine deficiency can cause disorders in alcoholic patients due to brain damage known as acute Wernicke's encephalopathy and Wernicke-Korsakoff syndrome [33].

In this work, we found a riboflavin (vitamin B2) concentration in donkey's milk of $0.168 \mu \mathrm{M}$, about double of the value found in the human milk [20], but much lower concerning the riboflavin concentration found in the bovine milk and in the goat milk (Table 2) $[2,3,27,31]$. In mare's milk, this vitamin showed a large variability $(0.076-1.28 \mu \mathrm{M})$ [28]. Riboflavin is the precursor of the cofactors flavin adenine mononucleotide (FMN), and flavin adenine dinucleotide (FAD), involved in the biological oxidation-reduction reaction. Furthermore, riboflavin is involved in the metabolism of folate, vitamin B12, and vitamin B6. A deficiency of riboflavin could occur in the case of dietary deprivation or stress, causing several clinical abnormalities, such as growth retardation, renal damage, anaemia, skin lesions, and nervous system impairment [34]. Riboflavin is particularly photosensitive: this is the reason why milk should be protected from light. Vitamin B2, on the other hand, does not undergo variations in the case of temperature treatment, and it is stable, even at high temperatures, as in the case of UHT milk [35].

The concentration of nicotinic acid in DM is $18.75 \mu \mathrm{M}$, a value higher with respect to human, bovine and mare's milk $[2,3,20,26,27,29]$, but very close to the value found in the goat milk $(22.5 \mu \mathrm{M})$ [31]. Nicotinic acid or niacin is a member of the B3 vitamin group showing lipid-lowering effects, since it suppresses the release of free fatty acids from adipocytes, reducing their levels in plasma and consequently reducing triglycerides and VLDL formation. It has been shown that nicotinic acid alters the expression of genes involved in the lipid metabolism, such as the diacylglycerol O-acyltransferase, an enzyme involved in the triglyceride synthesis [36].

This molecule is used as a drug in the treatment of lipid dysmetabolism, since it can help to reduce the progression of atherosclerotic cardiovascular disease [36,37]. Recently, other authors showed 
that the systemic administration in mice of nicotinic acid induces robust sleep and hypothermic responses [38].

Vitamin B6 (pyridoxine) concentration in DM is $5.38 \mu \mathrm{M}$ (Table 2), ten-fold higher, concerning the human and mare's milk [20,26,28], but close to that found in the bovine milk [2,3,27], and got milk [31]. Navrátilova and co-workers [28] found that in mare's milk there are large variations in pyridoxine values most probably linked to the lactation period. This vitamin is involved in several metabolic processes, such as amino acid metabolism, lipid metabolism and gluconeogenesis, and is involved in the proper development and functioning of the nervous system and the regulation of the immune response. The deficiency of vitamin B6 is frequent, especially among the elderly and in women of childbearing age, causing an impairment of the immune responses [39].

Very important in milk is the presence of folic, acid also known as vitamin B9. Milk represents a fundamental source of folic acid in children up to 1 year of age. The concentration of folic acid in donkey milk $(0.83 \mu \mathrm{M})$ is higher with respect to the other kind of milk taken into consideration in Table 2 . This is a significant result, since folic acid is involved in the nucleic acid synthesis, accelerates cell division, and consequently is important for the growth and development of the fetus [40]. Considering this, folic acid deficiency can cause several diseases, such as neural tube defects in new-born, megaloblastic anemia, cardiovascular disease, cancer, and Alzheimer's disease [41]. In untreated milk, native folate is essentially linked to FBP (folate binding protein). However, heat pasteurization and UHT treatments cause the loss of folic acid and a strong decrease in the concentration of FBPs and their binding capacity with this vitamin [42]. The value of vitamin B9 found in this work resulted in being higher with respect to that found by other authors in donkey milk $\left(3.6 \times 10^{-3} \mu \mathrm{M}\right)$ [43]. Finally, cyanocobalamin (vitamin B12) and nicotinamide were not detected in donkey milk. Nayak and co-workers [21] found that the level of vitamin B12 in the Indian small grey DM was below the limit of quantification, whereas in bovine milk vitamin B12 concentration is reported as $3.3 \times 10^{-3} \mu \mathrm{M}[3,5]$. The absence of this vitamin in donkey milk, compared to cow's milk could be explained by the different digestive systems between these two species, considering that vitamin B12 is produced by the microorganisms of the digestive tract. It will be interesting to study in depth the metabolism of vitamin B12 in donkey.

\section{Conclusions}

This work confirms, once again, the excellent nutraceutical properties of donkey milk, which, in addition to being a good source of bioactive proteins, is also an excellent source of vitamins. This milk contains valid amounts of nicotinic acid, which is known for its lipid-lowering effect, a good amount of vitamin B6, and appreciable quantities of folic acid, the latter very important for children's growth. Finally, it should be noted that the concentration of vitamin B6 has been determined for the first time in donkey milk. Previous works showed that donkey milk has hypoallergenic properties [44], possesses proteins with antimicrobial activity [10], has a considerable amount of vitamin C [19], vitamin D [23], nucleosides and nucleotides with sleep-inducing properties [45]. This study has demonstrated the presence of essential vitamins in donkey milk and confirmed that this milk is suitable for feeding children affected by CMPA that cannot be breastfed, but also that it can be appropriated for the elder people.

Author Contributions: Conceptualization: S.V. and P.P.; Formal analysis: S.V., G.S., Y.K. and S.P.; Methodology: S.V., Y.K. and G.S.; Data curation; S.V., V.P. and S.P.; Writing-original draft preparation: G.S., Y.K. and S.V.; Writing-review and editing: P.P., S.V. and V.P.; supervision, V.P., S.V. and S.P. All authors have read and agreed to the published version of the manuscript.

Funding: This research received no external funding.

Acknowledgments: The authors would like to thank Natalina Cammertoni for her excellent technical assistance, and Roberta Rapaccetti, owner of the farm "Mamma Asina" (Colmurano, MC, Italy) for providing us with donkey milk.

Conflicts of Interest: The authors declare no conflict of interest. 


\section{References}

1. Ball, G.F.M. Vitamins: Their Role in the Human Body; Blackwell Publishing Ltd.: London, UK, 2004; ISBN 9780632064786. [CrossRef]

2. INRAN (Istituto Nazionale di Ricerca per gli Alimenti e la Nutrizione). Libro Bianco Sul Latte e i Prodotti Lattiero Caseari: Analisi Delle Conoscenze Scientifiche e Considerazioni Sul Valore Del Consumo di Latte e Derivati; Assolatte, M., Ed.; Assolatte: Milano, Italy, 2006; Chapter 3; pp. 280-283.

3. Graulet, B.; Girard, C.L. B Vitamins in Cow Milk: Their Relevance to Human Health. In Dairy in Human Health and Disease across the Lifespan; Watson, R.R., Collier, R.J., Preedy, V.R., Eds.; Academic Press: Cambridge, MA, USA, 2017; Chapter 15; pp. 211-224, ISBN 9780128098684.

4. Linmark-Mansson, H.; Akesson, B. Antioxidant factors in milk. Br. J. Nutr. 2000, 84, S103-S110. [CrossRef] [PubMed]

5. Rutten, M.J.M.; Bouwman, A.C.; Sprong, R.C.; van Arendonk, J.A.M.; Viske, M.H.P.W. Genetic Variation in Vitamin B-12 Content of Bovine Milk and Its Association with SNP along the Bovine Genome. PLoS ONE 2013, 8, e62382. [CrossRef] [PubMed]

6. Duplessis, M.; Mann, S.; Nydam, D.V.; Girard, C.L.; Pellerin, D.; Overton, T.R. Short communication: Folates and vitamin B12 in colostrum and milk from dairy cows fed different energy levels during the dry period. J. Dairy Sci. 2015, 98, 5454-5459. [CrossRef] [PubMed]

7. Duplessis, M.; Pellerin, D.; Robichaud, R.; Fadul-Pacheco, L.; Girard, C.L. Impact of diet management and composition on vitamin $B_{12}$ concentration in milk of Holstein cows. Animal 2019, 13, 2101-2109. [CrossRef] [PubMed]

8. Poulsen, N.A.; Rybicka, I.; Poulsen, H.D.; Larsen, L.B.; Andersen, K.K.; Larsen, M.K. Seasonal variation in content of riboflavin and major minerals in bulk milk from three Danish dairies. Int. Dairy J. 2015, 42, 6-11. [CrossRef]

9. Schmidt, A.; Pratsch, H.; Schreiner, M.G.; Mayer, H.K. Determination of the native forms of vitamin B1 in bovine milk using a fast and simplified UHPLC method. Food Chem. 2017, 229, 452-457. [CrossRef] [PubMed]

10. Vincenzetti, S.; Polidori, P.; Mariani, P.; Cammertoni, N.; Fantuz, F.; Vita, A. Donkey's milk protein fractions characterization. Food Chem. 2008, 106, 640-649. [CrossRef]

11. Bertino, E.; Gastaldi, D.; Monti, G.; Baro, C.; Fortunato, D.; Perono Garoffo, L.; Coscia, A.; Fabris, C.; Mussap, M.; Conti, A. Detailed proteomic analysis on DM: Insight into its hypoallergenicity. Front. Biosci. 2010, 2, 526-536. [CrossRef]

12. Chianese, L.; Calabrese, M.G.; Ferranti, P.; Mauriello, R.; Garro, G.; De Simone, C.; Quarto, M.; Addeo, F.; Cosenza, G.; Ramunno, L. Proteomic characterization of donkey milk "caseome". J. Chromatogr. A 2010, 1217, 4834-4840. [CrossRef]

13. Vincenzetti, S.; Pucciarelli, S.; Polzonetti, V.; Polidori, P. Role of Proteins and of Some Bioactive Peptides on the Nutritional Quality of Donkey Milk and Their Impact on Human Health. Beverages 2017, 3, 34. [CrossRef]

14. Martini, M.; Altomonte, I.; Licitra, R.; Salari, F. Nutritional and nutraceutical quality of donkey milk. J. Equine Vet. Sci. 2018, 65, 33-37. [CrossRef]

15. Barni, S.; Sarti, L.; Mori, F.; Muscas, G.; Belli, F.; Pucci, N.; Novembre, E. Tolerability and palatability of donkey's milk in children with cow's milk allergy. Pediatr. Allergy Immunol. 2018, 29, 329-331. [CrossRef] [PubMed]

16. Tesse, R.; Paglialunga, C.; Braccio, S.; Armenio, L. Adequacy and tolerance to ass's milk in an Italian cohort of children with cow's milk allergy. Ital. J. Pediatr. 2009, 35, 19-22. [CrossRef] [PubMed]

17. Polidori, P.; Vincenzetti, S. Donkey milk production. In The Therapeutic, Nutritional and Cosmetic Properties of Donkey Milk; Cambridge Scholar Publishing: Newcastle upon Tyne, UK, 2019; Chapter 4; pp. 45-68, ISBN 978-1-5275-3967-9.

18. Salimei, E.; Fantuz, F.; Coppola, R.; Chiofalo, B.; Polidori, P.; Varisco, G. Composition and characteristics of ass's milk. Anim. Res. 2004, 53, 67-78. [CrossRef]

19. Vincenzetti, S.; Savini, M.; Cecchini, C.; Micozzi, D.; Carpi, F.; Vita, A.; Polidori, P. Effects of Lyophilization and Use of Probiotics on Donkey's Milk Nutritional Characteristics. Int. J. Food Eng. 2011, 7, 8. [CrossRef]

20. Ren, X.; Yang, Z.; Shao, B.; Yin, S.-A.; Yang, X. B-Vitamin Levels in Human Milk among Different Lactation Stages and Areas in China. PLoS ONE 2015, 10, e0133285. [CrossRef] 
21. Nayak, C.M.; Ramachandra, C.T.; Nidoni, U.; Hiregoudar, S.; Ram, J.; Naik, N. Physico-chemical composition, minerals, vitamins, amino acids, fatty acid profile and sensory evaluation of donkey milk from Indian small grey breed. J. Food Sci. Technol. 2020, 57, 2967-2974. [CrossRef]

22. Walstra, P.; Jenness, R. Dairy Chemistry and Physics; John Wiley and Sons: New York, NY, USA, 1984; ISBN 9780471097792-467.

23. Martini, M.; Altomonte, I.; Licitra, R.; Salari, F. Short communication: Technological and seasonal variations of vitamin D and other nutritional components in donkey milk. J. Dairy Sci. 2018, 101, 8721-8725. [CrossRef]

24. Albalá-Hurtado, S.; Veciana-Nogués, T.; Izquierdo-Pulido, M.; Mariné-Font, A. Determination of water-soluble vitamins in infant milk by high performance liquid chromatography. J. Chromatogr. A 1997, 778, 247-253. [CrossRef]

25. FAO/WHO. Human Vitamin and Mineral Requirements; Report of a Joint FAO/WHO Expert Consultation, Bangkok, Thailand; Food and Nutrition Division, FAO: Rome, Italy, 2001.

26. Han, Y.-E.; Yon, M.; Han, H.-S.; Kim, K.-Y.; Tamura, T.; Hyun, T.H. Folate contents in human milk and casein-based and soya-based formulas, and folate status in Korean infants. Br. J. Nutr. 2009, 101, 1769-1774. [CrossRef]

27. Haug, A.; Høstmark, A.T.; Harstad, O.M. Bovine milk in human nutrition-A review. Lipids Health Dis. 2007, 6, 25. [CrossRef] [PubMed]

28. Navrátilová, P.; Borkovcová, I.; Kaniová, L.; Dluhošová, S.; Zachovalová, H. The content of selected vitamins and iodine in mare's milk. Acta Vet. Brno 2019, 88, 473-480. [CrossRef]

29. Pieszka, M.; Łuszczyński, J.; Zamachowska, M.; Augustyn, R.; Długosz, B.; Hędrzak, M. Is mare milk an appropriate food for people?-A review. Ann. Anim. Sci. 2016, 16, 33-51. [CrossRef]

30. Sawaya, W.N.; Khalil, J.K.; Al-Shalhat, A.F. Mineral and Vitamin Content of Goat's Milk. J. Am. Diet. Assoc. 1984, 84, 433-435. [PubMed]

31. Turkmen, N. The Nutritional Value and Health Benefits of Goat Milk Components. In Nutrients in Dairy and Their Implications on Health and Disease; Ross Watson, R., Collier, R.J., Preedy, V.R., Eds.; Academic Press: Cambridge, MA, USA, 2017; Chapter 35; pp. 441-449.

32. Di Nicolantonio, J.J.; Liu, J.; O’Keefe, J.H. Thiamine and cardiovascular disease: A literature review. Prog. Cardiovasc. Dis. 2018, 61, 27-32. [CrossRef]

33. Nardone, R.; Höller, Y.; Storti, M.; Christova, M.; Tezzon, F.; Golaszewski, S.; Trinka, E.; Brigo, F. Thiamine Deficiency Induced Neurochemical, Neuroanatomical, and Neuropsychological Alterations: A Reappraisal. Sci. World J. 2013, 201, 309143. [CrossRef]

34. Thakur, K.; Tomar, S.K.; Singh, A.K.; Mandal, S.; Arora, S. Riboflavin and health: A review of recent human research. Crit. Rev. Food Sci. Nutr. 2017, 57, 3650-3660. [CrossRef] [PubMed]

35. Pizzoferrato, L. Trattamenti termici del latte: Effetti sul contenuto in riboflavina. In: Effetti dei trattamenti termici industriali sulle caratteristiche microbiologiche, fisiche, chimiche nutrizionali ed organolettiche del latte. Monogr. Quad. Della Nutr. 1992, 6, 101-105.

36. Kang, I.; Kim, S.-K.; Youn, J.H. Effects of Nicotinic Acid on Gene Expression: Potential Mechanisms and Implications for Wanted and Unwanted Effects of the Lipid-Lowering Drug. J. Clin. Endocrinol. Metab. 2011, 96, 3048-3055. [CrossRef] [PubMed]

37. Carlson, L.A. Nicotinic acid: The broad-spectrum lipid drug. A 50th anniversary review. J. Intern. Med. 2005, 258, 94-114. [CrossRef] [PubMed]

38. Szentirmai, É.; Kapás, L. Nicotinic acid promotes sleep through prostaglandin synthesis in mice. Sci. Rep. 2019, 9, 17084. [CrossRef] [PubMed]

39. Qian, B.; Shen, S.; Zhang, J.; Jing, P. Effects of Vitamin B6 Deficiency on the Composition and Functional Potential of T Cell Populations. J. Immunol. Res. 2017, 2017, 2197975. [CrossRef]

40. Czeizel, A.E. Folic Acid/Folic Acid-Containing Multivitamins and Primary Prevention of Birth Defects and Preterm Birth. In Preventive Nutrition. Nutrition and Health; Bendich, A., Deckelbaum, R., Eds.; Humana Press: Totowa, NJ, USA; Springer Nature: New York, NY, USA, 2010; pp. 643-672.

41. Batra, B.; Narwal, V.; Kalra, C.; Sharma, M.; Rana, J.S. Folic acid biosensors: A review. Process Biochem. 2020, 92, 343-354. [CrossRef]

42. Wigertz, K.; Hansen, I.; Høier-Madsen, M.; Holm, J.; Jägerstad, M. Effect of milk processing on the concentration of folate-binding protein (FBP), folate binding capacity and retention of 5-methyltetrahydrofolate. Int. J. Food Sci. Nutr. 1996, 47, 315-322. [CrossRef] [PubMed] 
43. Tidona, F.; Charfi, I.; Povolo, M.; Pelizzola, V.; Carminati, D.; Contarini, G.; Giraffa, G. Fermented beverage emulsion based on donkey milk with sunflower oil. Int. J. Food Sci. Technol. 2015, 50, 2644-2652. [CrossRef]

44. Vincenzetti, S.; Foghini, L.; Pucciarelli, S.; Polzonetti, V.; Cammertoni, N.; Beghelli, D.; Polidori, P. Hypoallergenic Properties of Donkey's Milk: A Preliminary Study. Vet. Ital. 2014, 50, 99-107.

45. Vincenzetti, S.; Pucciarelli, S.; Nucci, C.; Polzonetti, V.; Cammertoni, N.; Polidori, P. Profile of Nucleosides and Nucleotides in Donkey's Milk. Nucleosides Nucleotides Nucleic Acids 2014, 33, 656-667. [CrossRef]

(C) 2020 by the authors. Licensee MDPI, Basel, Switzerland. This article is an open access article distributed under the terms and conditions of the Creative Commons Attribution (CC BY) license (http://creativecommons.org/licenses/by/4.0/). 